\title{
Variation in Ancient Egyptian Stature and Body Proportions
}

\author{
Sonia R. Zakrzewski ${ }^{*}$ \\ Department of Archaeology, University of Southampton, Southampton SO17 1BF, UK \\ KEY WORDS $\quad$ stature; limb proportions; social complexity; SES; Egypt
}

\begin{abstract}
Stature and the pattern of body proportions were investigated in a series of six time-successive Egyptian populations in order to investigate the biological effects on human growth of the development and intensification of agriculture, and the formation of state-level social organization. Univariate analyses of variance were performed to assess differences between the sexes and among various time periods. Significant differences were found both in stature and in raw long bone length measurements between the early semipastoral population and the later intensive agricultural population. The size differences were greater in males than in females. This dis-
\end{abstract}

Within Egypt, the transition from a mainly pastoral and nomadic lifestyle to a settled agricultural subsistence pattern coincided with the development of state-level and hierarchical social organization. These latter changes occurred very rapidly, and should have had a radical impact on the biology of the local population. In less than 2,000 years, the Egyptian population changed from being an egalitarian hunter-gatherer/pastoral population to a highly ranked agricultural hierarchy with the pharaoh as the divine ruler.

\section{HUMAN GROWTH, INFECTION, AND AGRICULTURE}

Human growth is an outcome of complex interactions between genes and the environment, of which nutrition and infection are the most important components. Poor nutritional status can lead to impaired immunocompetence and reduced resistance to infection, and/or exposure to infectious disease can lead to a combination of anorexia, malabsorption, and/or elevated basal metabolic rate due to fever and protein catabolism (King and Ulijaszek, 1999). The development of agriculture usually leads to an increase in the prevalence and intensity of infectious disease, linked to the associated increase in population density and sedentism (e.g., Cook, 1984; Meiklejohn et al., 1984). A decline in the quality of nutrition with the adoption of agriculture is frequently experienced (Cohen, 1989a,b; Larsen, 1995, 1997). This change in subsistence practice may be linked with a reduction in bone area and maintenance (Cook, 1984; Goodman et al., 1984), parity is suggested to be due to greater male response to poor nutrition in the earlier populations, and with the increasing development of social hierarchy, males were being provisioned preferentially over females. Little change in body shape was found through time, suggesting that all body segments were varying in size in response to environmental and social conditions. The change found in body plan is suggested to be the result of the later groups having a more tropical (Nilotic) form than the preceding populations. Am J Phys Anthropol 121:219-229, 2003.

๑ 2003 Wiley-Liss, Inc.

retardation of individual childhood growth (Goodman et al., 1984; Martin et al., 1984), reduction in the size and robusticity of the adult population (Angel, 1972; Larsen, 1984), or a reduction in other specific skeletal dimensions (Angel, 1984), as less buffering of growth occurs during of periods of stress in early agricultural populations than in the preceding hunter-gatherer period or in neighboring hunter-gatherer groups (Ulijaszek and Strickland, 1993).

This relationship between infection and malnutrition has a cyclical effect. Poorly nourished individuals are more susceptible to infection, and infection worsens nutritional status (Ulijaszek and Strickland, 1993). Individuals with relatively poor diets suffer proportionally more from the effects of infection, such as poor individuals in early agricultural groups relative to highly ranked individuals in complex state societies. With the development of social ranking, preferential access to food and healthcare

\footnotetext{
Grant sponsor: Bioarchaeology Panel, Wellcome Trust; Grant sponsor: St. John's College, University of Cambridge; Grant sponsor: Addison Wheeler Fellowship, University of Durham.

*Correspondence to: Sonia Zakrzewski, Department of Archaeology, University of Southampton, Southampton SO17 1BF, UK.

E-mail: S.R.Zakrzewski@soton.ac.uk
}

Received 19 February 2002; accepted 11 November 2002.

DOI 10.1002/ajpa.10223 
might also develop, and might be reflected in each individual's skeletal biology. A series of studies indicated that, in most past societies, elites were taller, healthier, or better fed than the poorer members (Allison, 1984; Angel, 1984; Cohen, 1989a; Cook, 1984; Haviland, 1967; Schoeninger, 1979; Steegmann and Haseley, 1988), although others found little or no difference between commoners and elites (White et al., 1993).

\section{DEVELOPMENT OF BODY SHAPE AND SIZE}

Bones (and limbs) have differing growth curves (Harrison, 1992). At all ages, the dimensions of the head are nearer maturity (in advance) than those of the trunk, the trunk is in advance of the limbs, and the more peripheral parts of the limbs are in advance of the more proximal portions (Harrison, 1992; Sinclair, 1989). Maturity is advanced distally relative to delayed maturity proximally. Maximum growth is attained first by the tibia, then the femur, then the fibula, and after that the bones of the upper extremity (Malina and Bouchard, 1991).

Since different parts of the body experience growth spurts at different times, they have differing "sensitive" periods. A major insult, such as food shortage, will therefore differentially affect portions of the body so that portions of the body can be stunted to differing levels. Stunting usually occurs during the childhood period of growth, thereby mainly affecting the limbs (Martorell and Habicht, 1986).

Growth impairment through the first few years of life largely determines the small stature exhibited by adults from modern developing countries. Within a malnourished population, those who exhibit a great degree of stunting as young children are those who are later the shortest adults. If very early developmental events program abnormal growth to occur during a particular period, there may not be the capacity or stimulus to catch up when the child enters a later period (Golden, 1996).

Thus, adult stature can be considered a reasonable indicator of childhood condition, following the model shown in Figure 1.

\section{EGYPTIAN SUBSISTENCE STRATEGY AND SOCIAL ORGANIZATION}

As summarized earlier, the intensification of agriculture and the formation of the Dynastic state occurred over the same period in Egypt. This drastic change in social organization and the accompanying change in subsistence strategy will be reflected in the skeletal biology of the indigenous population. This subsistence change should be experienced to a greater biological extent, and thus with greater skeletal effect, by the poorer sections of Egyptian society.

The Neolithic and Chalcolithic period, predating the Pharaonic period in Egypt, is referred to as the Predynastic period. In this study, it is broken down

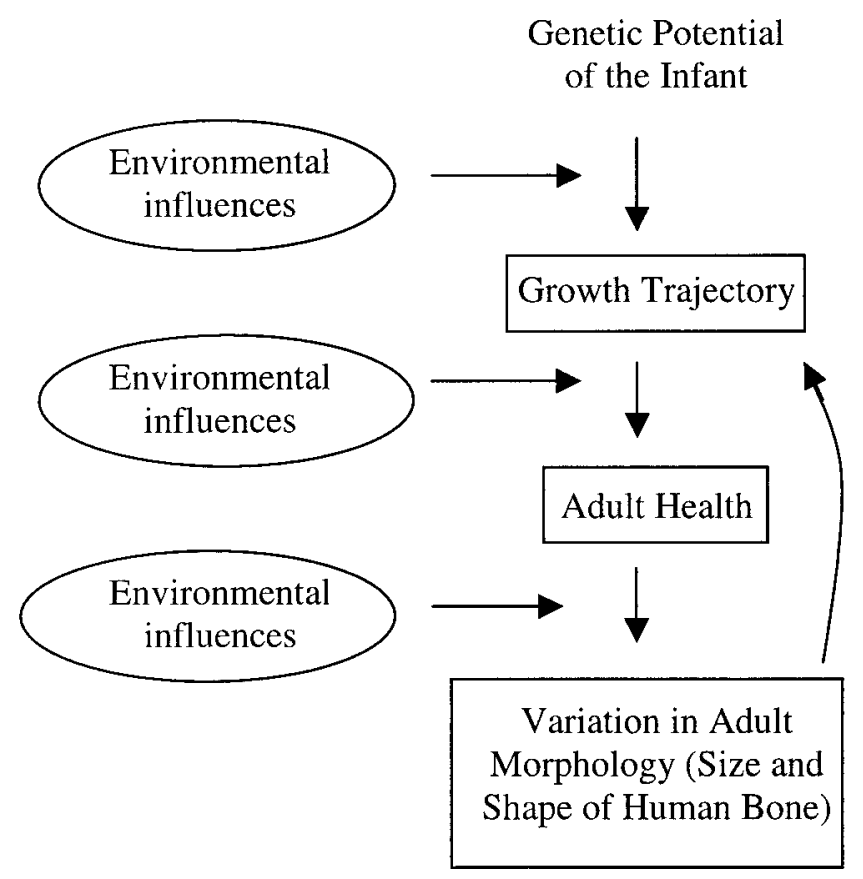

Fig. 1. Model predicting effects of changes in patterns of subsistence and social hierarchy on adult body size and shape.

into three distinct periods: the Badarian (ca. 50003900 BC), Early Predynastic (EPD, ca. 3900-3500 BC), and Late Predynastic (LPD, ca. 3500-3100 $\mathrm{BC})$. The Pharaonic period is broken down into Dynasties. The first two are collectively known as the Early Dynastic period (EDyn, ca. 3100-2700 BC), and the next few as the Old Kingdom (OK, ca. 2700$2200 \mathrm{BC}$ ). The OK is followed by the First Intermediate Period (not included in the present study), and then by the Middle Kingdom (MK, ca. 2000-1800 $\mathrm{BC})$.

The Badarian population practiced both cereal gathering and cultivation, with wheat, barley, lentils, and tubers found in Badarian storage facilities (Hendrickx and Vermeersch, 2000). Fishing, especially of Nile perch (Brewer and Friedman, 1989), was also of major importance, and may have been the principal economic activity at certain times of year (Hendrickx and Vermeersch, 2000). Despite the presence of wild bovine remains at El-Badari (Brunton and Caton-Thompson, 1928), it appears that hunting was only of marginal importance (Hendrickx and Vermeersch, 2000). Other cereal domesticates (principally emmer) were slowly added to the subsistence system through the Predynastic period (Brewer et al., 1994), so that by the LPD, barley, wheat, and peas were dietary staples (Midant-Reynes, 2000a). It was not, however, until the MK and the development of large-scale irrigation that total reliance on agriculture was possible (Brewer et al., 1994), although food production through cultivation became much more organized and coordinated during the OK (Malek, 2000). Animal domestication, especially of goats, sheep, and pigs, also occurred 
during the LPD (Midant-Reynes, 2000a), although large numbers of domestic cattle are not found in Upper Egypt until the start of the Dynastic period (Darby et al., 1977).

Associated with the change in subsistence strategy was a change in settlement pattern and population density, mainly due to the development of large towns such as Abydos, El-Amrah, and Hierakonpolis (Brewer et al., 1994). Butzer (1976) estimated that during the LPD, approximately $16,000 \mathrm{~km}^{2}$ were under cultivation, which could support 300,000 inhabitants. By the OK the population had risen to 1.5 million, with most living in towns. This urbanization mainly developed during the LPD. During the OK, however, these towns became bigger and more internally differentiated, with large cities developing during the MK (Brewer and Teeter, 1999).

As described previously, the social organization of the Egyptian population changed tremendously over the period considered. A major transition occurred after the EPD from a poor and egalitarian society to a society that was materially more prosperous and stratified along class lines. At the peak of Dynastic social organization was the Pharaoh and his family. Ranked directly below the Pharaoh were his court officials in the city, and overseers, market farmers, estate managers, and priests in the provinces. Below them lay skilled craftsmen and scribes, while at the bottom of the social ranking were the farm-laborers, herders, fishermen, and others involved in manual occupations. Craft specialization developed during the LPD and led to a rapid increase in social stratification (Trigger, 1983).

The development in social hierarchy can also be recognized from mortuary studies. The graves and funerary offerings of the EPD indicate increasing social diversity rather than hierarchization (Midant-Reynes, 2000a). A dramatic increase in the number of burial goods included in the graves occurred after the EPD, and was followed by a more moderate increase after the LPD (Castillos, 1983; Midant-Reynes, 2000b). The distribution of rich graves within actual cemeteries was entirely random during the Badarian and EPD, but showed a progressive tendency for the clustering of richer graves in later periods. Later, during the Early Dynastic period, the higher ranked individuals were buried in separate cemeteries (Castillos, 1983). Thus, in early Egyptian society, social division occurred mainly due to hierarchical rank rather than sex or gender.

The present study attempts to examine the biological changes associated with both the intensification of agriculture and the development of a complex social hierarchy within a series of time-successive Egyptian Nile Valley populations, and assumes indigenous state formation processes. The study concentrates on the period of development of complex economic systems and the formation of a highly socially stratified society.

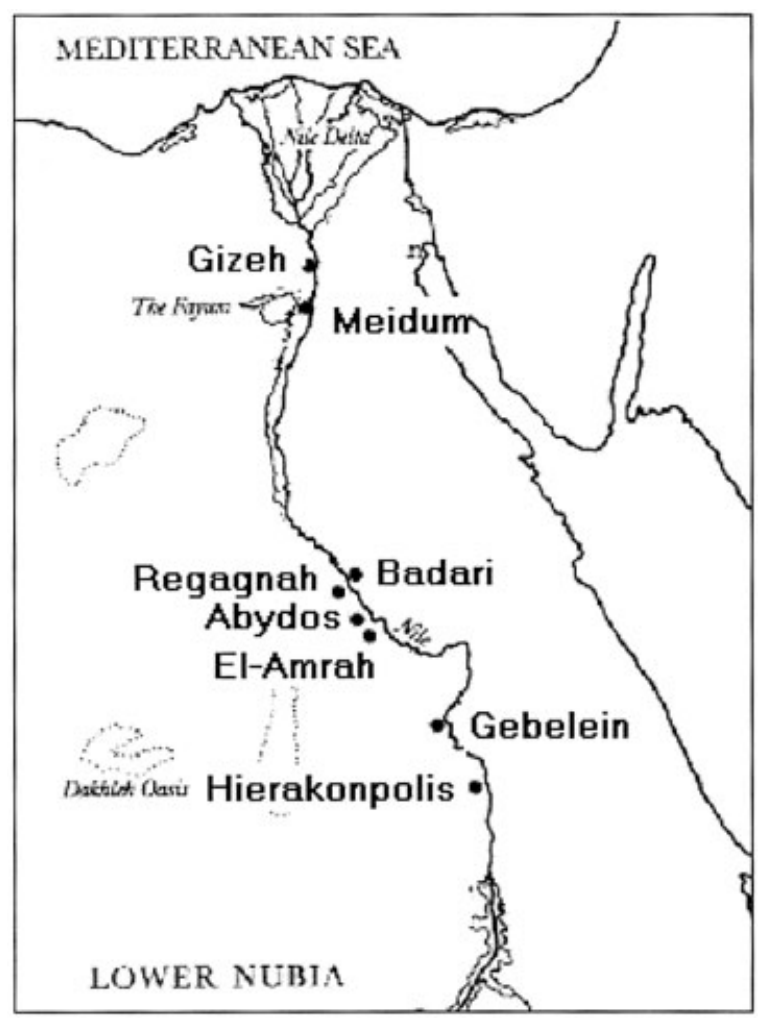

Fig. 2. Map of Egypt, indicating locations of sites.

\section{MATERIALS AND METHODS}

Skeletal sampling was mainly restricted to sites from Middle and Upper Egypt, so that all individuals would have experienced reasonably similar geographical and climatic conditions. Due to the lack of OK postcranial remains from Upper Egypt, one series from Lower Egypt was also analyzed. The site locations are shown in Figure 2.

The selection of skeletal material was mainly pragmatic. For most periods, all available material was assessed. Care was taken to maximize samples from all available time periods.

Four collections were studied: the Duckworth Collection of the Department of Biological Anthropology in Cambridge, the Egyptian collection of the Natural History Museum in London, the Marro Collection of the Department of Anthropology and Biology in Turin, and the Reisner Collection of the Natural History Museum in Vienna.

Groups from six time period groups were studied, dating from the Badarian (ca. $4000 \mathrm{BC}$ ) to the MK (ca. 1900 BC). Samples were studied only if they could be reliably dated to one of the six periods. A total of 150 individuals was measured. Although this sample is small, it represents a large proportion of the postcranial Egyptian skeletal material in $\mathrm{Eu}-$ ropean museum and university collections. The samples are shown in Table 1. 
TABLE 1. Samples studied ${ }^{1}$

\begin{tabular}{|c|c|c|c|c|c|}
\hline Time period & $\begin{array}{c}\text { Years BC } \\
\text { (approximate) }\end{array}$ & Site(s) & $\mathrm{N}$ (total) & $\mathrm{N}$ (males) & $\mathrm{N}$ (females) \\
\hline Badarian & $5000-3900$ & El-Badari & 10 & 6 & 4 \\
\hline EPD & $3900-3500$ & Abydos and Gebelein & 60 & 28 & 32 \\
\hline LPD & $3500-3100$ & El-Amrah & 11 & 4 & 7 \\
\hline EDyn & $3100-2700$ & Abydos and El-Amrah & 22 & 11 & 11 \\
\hline $\mathrm{OK}$ & $2700-2200$ & Meidum \& Gizeh & 25 & 16 & 9 \\
\hline MK & $2000-1800$ & Gebelein & 22 & 13 & 9 \\
\hline Total & & & 150 & 78 & 72 \\
\hline
\end{tabular}

${ }^{1}$ EPD,Early Predynastic; LPD, Late Predynastic; EDyn, Early Dynastic; OK, Old Kingdom; MK, Middle Kingdom.

\section{Description of samples}

Material from several cemetery sites was pooled for most periods, so as to diminish the effects of bias due to familial groupings or social ranking. This was not possible for the earliest period, the Badarian, where all material originates from the period typesite of el-Badari.

The EPD material was obtained from Abydos cemetery $\phi$ (13 males and 13 females) and Gebelein (15 males and 19 females). Although little social hierarchy had yet developed in Egypt, the settlement at Abydos was larger in size than Gebelein at the time, and might be presumed to have greater social diversity and possibly greater social complexity.

The LPD material was all from El-Amrah. These graves were furnished with prestige materials such as ivory, lapis lazuli, copper, silver, and gold (Wilkinson, 1999), showing the relatively high ranking of the local population and their access to, and possibly control of, long-distance trade. The site of el-Amrah developed throughout the Predynastic periods, but reached its pinnacle during the LPD.

The EDyn material mainly originated from Abydos (13 males and 11 females, of whom 3 males and 4 females derived from the Tombs of the Courtiers cemetery), while El-Amrah provided 1 male and 1 female. The Tombs of the Courtiers sample consists of individuals who may have been funerary priests (Hoffman, 1979), minor palace functionaries, members of the royal harem, or artisans (Trigger, 1983). These individuals ("retainers") were probably killed so that they could continue to serve their king after death (Trigger, 1983), and so may be individuals who were wealthier and healthier than the average Egyptian EDyn person. They were buried in subsidiary tombs surrounding the tombs of the pharaohs. The remainder of the Abydos EDyn material was derived from Cemetery $\chi$, and may represent a poorer section of Abydos society. Cemetery $\chi$ is located south of the valley leading to the Royal Tombs at Umm el-Qaab, to the west of the Seti Temple (Duhig, 2000). The strong links between the town itself and the royal court mean that the EDyn period material included in this study may be somewhat unrepresentative of the national Egyptian population of the time, as the sample may represent favored individuals and families.

The OK material was derived from Meidum (3 males and 4 females) and Gizeh (13 males and 5 females). The Meidum material comes from the lesser pit burials of the poor around the Meidum pyramid (Petrie, 1892). Although this material has been described as being from the "poor," it is likely that this preferential location for burial would have only been available to a selected cross section of the population, and thus again may be unrepresentative of the OK population as a whole. The Gizeh material comes from the western necropolis attached to Cheops' pyramid (Leek, 1986), and therefore is the skeletal material of Cheops' attendants (Aldred, 1998).

The MK material all derives from Gebelein. Evidence from stelae suggests that, by the MK, Gebelein had a colony of Nubian mercenaries who married into the local Egyptian population (Fischer, 1961). These stelae indicate that the Nubian mercenaries lived with and were buried near the Egyptian community they served, and that they were buried in an Egyptian manner. The sample included in this study may thus represent Nubians, Egyptians, or some of each group.

\section{Methods}

The analysis was limited to adult individuals, with maturity determined on the basis of sphenooccipital fusion, full epiphyseal fusion, and complete eruption of the third molars. All individuals were assigned a sex. The sex of each individual was primarily determined from analysis of the pelvic region, by assessing the size of the pubic angle, the size of the greater sciatic notch, and the curvature of the sacrum, noting the presence or absence of ventral arc and subpubic concavity, and the relative lengths of the inferior ramus of the pubis and the distance from the pubic tubercle to the acetabulum. Postcranial sex was compared with the cranially determined sex. Cranial sex was assessed from the degree of supraorbital and glabellar projection, the squareness of the anterior portion of the mandible, the flaring of the gonial region, the robustness and level of muscle development in the nuchal region, and other features such as the general size of the cranium with respect to others in the sample. The size of the mastoids was considered, but all Egyptian cranial material studied has relatively inflated mastoids as compared to other populations.

Following sexing, each long bone was measured individually, following Martin and Saller (1957) and 
TABLE 2. Measurements taken

\begin{tabular}{|c|c|c|c|}
\hline Variable name & $\begin{array}{l}\text { Variable } \\
\text { code }\end{array}$ & $\begin{array}{l}\text { Martin/Bräuer } \\
\text { number }\end{array}$ & Description \\
\hline Maximum femur length & $\mathrm{XLF}$ & 1 & $\begin{array}{l}\text { Maximum length, moving bone in long-bone board to find maximum } \\
\text { measurement }\end{array}$ \\
\hline Bicondylar femur length & $\mathrm{LBF}$ & 2 & $\begin{array}{l}\text { Physiological bicondylar length, length measured with condyles } \\
\text { placed against upright of long-bone board }\end{array}$ \\
\hline Complete tibia length & LCT & 1 & $\begin{array}{l}\text { Complete length, excluding tibial spine, from tibial plateau to most } \\
\text { distal point of medial malleolus }\end{array}$ \\
\hline Maximum tibia length & XLT & $1 \mathrm{a}$ & $\begin{array}{l}\text { Maximum length, including tibial spine, from most proximal point } \\
\text { of intercondylar tubercles to most distal point of medial malleolus }\end{array}$ \\
\hline Maximum fibula length & XLG & 1 & $\begin{array}{l}\text { Maximum length, from most proximal point of styloid process to } \\
\text { most distal point of lateral malleolus }\end{array}$ \\
\hline Maximum humerus length & XLH & 1 & $\begin{array}{l}\text { Maximum length from most proximal point of femoral head to most } \\
\text { distal point of the trochlea }\end{array}$ \\
\hline Maximum radius length & XLR & 1 & $\begin{array}{l}\text { Maximum length, from most proximal point of radial head to most } \\
\text { distal point of styloid process }\end{array}$ \\
\hline Maximum ulna length & XLU & 1 & $\begin{array}{l}\text { Maximum length, from proximal point of olecranon process to most } \\
\text { distal point of styloid process }\end{array}$ \\
\hline
\end{tabular}

Bräuer (1988). The total sample consisted of 997 long bones. Where long bones were bilaterally present, mean measurements were calculated and used in the analyses. The measurements are summarized in Table 2.

\section{Data analysis}

All variables were tested for normality using P-P and Q-Q plots. Stature, raw long bone lengths, and ratios (indices) were analyzed using univariate analysis of variance, employing a type I (hierarchical or nested) model (Sokal and Rohlf, 1995), with post hoc tests, for differences among the various time periods, while correcting for sex. The model allows differences between the sexes to be analyzed first, and after the effects of sex are removed, to assess for statistically significant differences among the various time periods. Thus, in all the analyses that follow, the independent variable in each ANOVA is time period (i.e., population group, such as Badarian or EPD). Throughout the analyses, an $\alpha$-level of 0.05 was employed. Sample-size-corrected coefficients of variation $\left(\mathrm{V}^{*}\right)$ of calculated stature were also compared (Sokal and Rohlf, 1995).

\section{RESULTS}

Stature was computed using equations derived by Robins and Shute (1986) specifically for Egyptian populations. The computed adult statures are shown in Figure 3 (mean data in Table 3). Table 4 presents the ANOVA results for computed mean stature by time period. Males are shown to be significantly taller than females in all time periods, and overall, a significant change in stature occurs across the time periods studied.

The pattern of change in stature differs between males and females. Both sexes exhibit the smallest stature in the Badarian period, and have a rapid gain in height through the Early Predynastic period. Male stature reaches a maximum during the Early Dynastic period, while females continue to increase (albeit very slightly) in height until the OK. Both

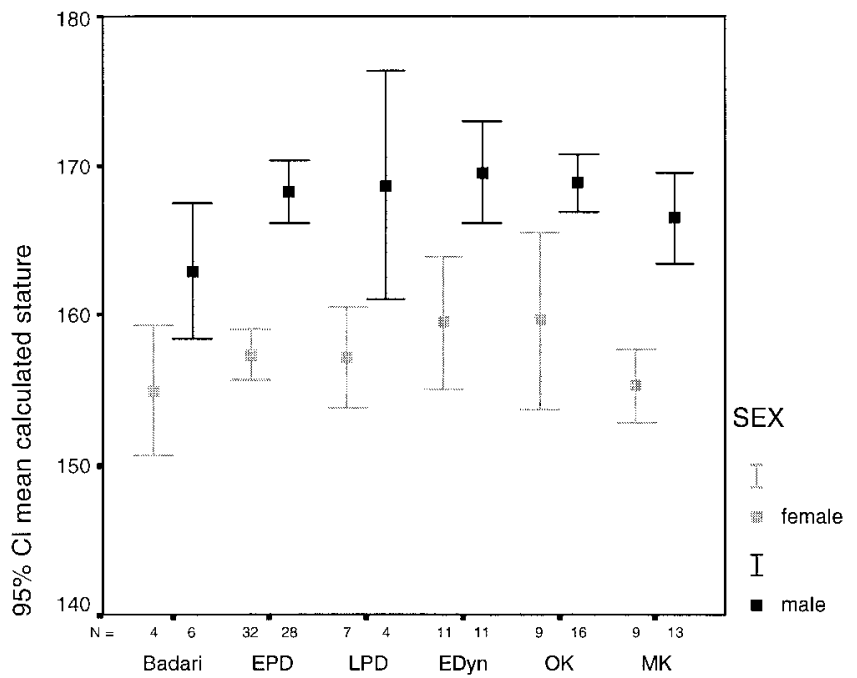

Fig. 3. Average computed adult stature by time period for each sex. Mean values, sample sizes, and 95\% confidence intervals are shown.

sexes exhibit a decline in computed stature between the Early Dynastic period and the MK.

The coefficients of variation for the computed statures for each time period are plotted in Figure 4. Figure 4 indicates that over the start of the Dynastic period, greater variation is found in the computed statures of females than males, and that the reverse is true by the MK.

In order to determine which portion of the body had changed significantly in size through time, each long bone was in turn analyzed employing the same hierarchical model (correcting for sex before analyzing for differences among time periods). The results are shown in Table 5.

All long bone lengths exhibit significant sexual dimorphism, and several exhibit statistically significant changes in length among the various time periods. An example of one of these long bone length changes through time, the complete length of the tibia, is plotted in Figure 5. All long bones, except 
TABLE 3. Mean femur and tibia length measurements and mean computed stature by sex and time period ${ }^{1}$

\begin{tabular}{llcc}
\hline Period & \multicolumn{1}{c}{ XLF $(\mathrm{mm})$} & LCT $(\mathrm{mm})$ & Computed stature $(\mathrm{cm})$ \\
\hline Female & & & \\
Badari & $410.5 \pm 9.3(4)$ & $345.3 \pm 10.5(3)$ & $154.9 \pm 2.7(4)$ \\
EPD & $414.8 \pm 23.7(16)$ & $353.5 \pm 21.9(24)$ & $157.3 \pm 4.7(32)$ \\
LPD & $420.3 \pm 20.2(5)$ & $350.0 \pm 14.7(6)$ & $157.2 \pm 3.7(7)$ \\
EDyn & $428.2 \pm 41.4(3)$ & $361.5 \pm 28.6(8)$ & $159.5 \pm 6.6(11)$ \\
OK & $425.6 \pm 20.4(8)$ & $368.7 \pm 31.7(7)$ & $159.6 \pm 7.7(9)$ \\
MK & $412.5 \pm 16.7(9)$ & $345.1 \pm 13.9(9)$ & $155.2 \pm 3.2(9)$ \\
Total & $417.4 \pm 21.5(45)$ & $354.4 \pm 22.6(57)$ & $157.5 \pm 5.2(72)$ \\
Male & & & \\
Badari & $431.1 \pm 17.0(6)$ & $351.8 \pm 12.3(6)$ & $162.9 \pm 4.3(6)$ \\
EPD & $445.4 \pm 26.0(11)$ & $379.6 \pm 19.1(18)$ & $168.3 \pm 5.5(28)$ \\
LPD & $449.0 \pm 7.1(2)$ & $378.8 \pm 21.4(3)$ & $16.6 \pm 1.3(9)$ \\
EDyn & $458.6 \pm 28.1(8)$ & $381.3 \pm 11.2(10)$ & $169.6 \pm 5.1(11)$ \\
OK & $451.7 \pm 19.5(12)$ & $371.2 \pm 28.0(13)$ & $168.8 \pm 3.6(16)$ \\
MK & $436.6 \pm 24.6(13)$ & $375.7 \pm 21.1(59)$ & $166.4 \pm 5.1(13)$ \\
Total & $445.2 \pm 24.0(52)$ & & $167.9 \pm 5.1(78)$ \\
\hline
\end{tabular}

${ }^{1} \mathrm{XLF}$, maximum femur length; LCT, complete tibia length. Sample sizes are in parentheses.

TABLE 4. ANOVA results for computed mean stature by time period, employing hierarchical model, correcting initially for sex

\begin{tabular}{|c|c|c|c|c|c|}
\hline Source & Type I sum of squares & $\mathrm{df}$ & Mean square & $\mathrm{F}$ & $P$ \\
\hline Sex & $4,029.617$ & 1 & $4,029.617$ & 157.273 & $<0.001$ \\
\hline Period & 351.331 & 5 & 70.266 & 2.742 & 0.021 \\
\hline Sex $*$ Period & 34.977 & 5 & 6.995 & 0.273 & 0.927 \\
\hline Error & $3,535.800$ & 138 & 25.622 & & \\
\hline Total & $7,951.724$ & 149 & & & \\
\hline
\end{tabular}

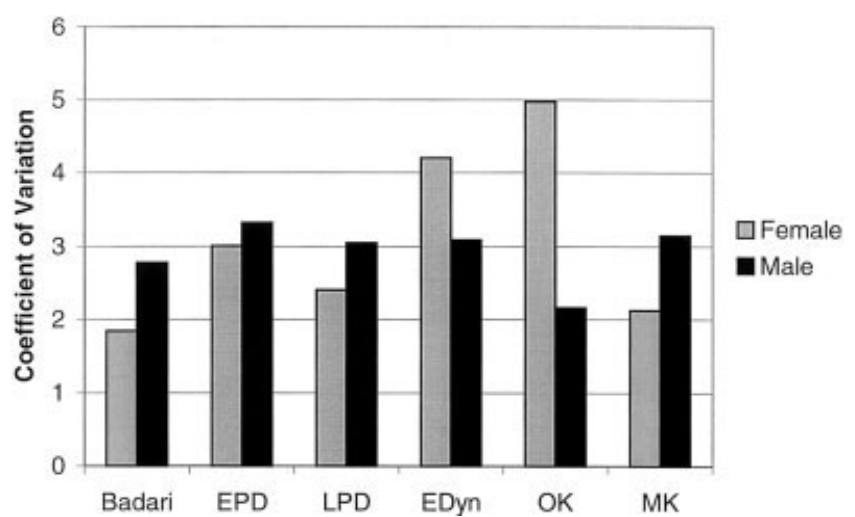

Fig. 4. Variance in computed adult stature (as indicated by sample size corrected coefficients of variation) by time period. CV $\left(\mathrm{V}^{*}\right)$ was computed following Sokal and Rohlf (1995) as $\mathrm{V}^{*}$ $=(1+1 / 4 \mathrm{n})(100 \mathrm{~s} / \overline{\mathrm{x}})$ where $\mathrm{n}$ is sample size, $\mathrm{s}$ is standard deviation, and $\overline{\mathrm{x}}$ is mean stature.

the fibula, exhibit some trend towards a change in length through time.

Since significant differences between the sexes were seen, both in computed stature and in all long bone lengths, the degree of sexual dimorphism in stature was also investigated. Figure 6 shows female stature as a proportion of male stature by time period. The Badarian sample clearly has greater similarities in computed statures than all the other time periods. The most sexual dimorphism is seen during the LPD, with high levels also found during the MK.

Hierarchical ANOVAs were also performed on long bone ratios and indices. The results of these, including crural and brachial indices, are shown in
Table 6. By computing ratios, it is the relationship of the segments to each other that is studied, rather than absolute lengths. This means that the major effects of sexual dimorphism should therefore be removed. This asexual standardization is found for all ratios and indices, except the intermembral index (which continues to exhibit statistically significant differences between sexes). The significant result found in the latter may result from differing body plans in males and females (i.e., females have significantly longer lower limbs relative to their upper limbs than males). The males actually have both upper and lower limbs that are significantly longer than those of the females (upper limb length, $P<$ $0.001, \mathrm{n}=83$; lower limb length, $P<0.001, \mathrm{n}=86$ ).

The ratio of maximum humerus length to maximum ulna length (XLH/XLU) shows a reduction through time. Plotting each of the lengths separately by time period shows that maximum humerus length (XLH) follows the same bow-like pattern seen in Figures 3 and 5, while maximum ulna length (XLU) increases in length through time, especially in males.

The group data were also compared with population mean values obtained from Ruff (1994). Tibia length relative to femur length is plotted in Figure 7.

\section{DISCUSSION}

The development of intensive agriculture and the formation of hierarchical social organization occurred almost simultaneously along the Egyptian Nile valley. If these processes occurred as an indigenous development with total population continuity, then biological changes found within the skeletal 
TABLE 5. ANOVA results for long bone lengths by time period, employing hierarchical model, correcting initially for sex ${ }^{1}$

\begin{tabular}{lrcccc}
\hline & & \multicolumn{2}{c}{ Sex } & \multicolumn{2}{c}{ Time period } \\
\cline { 3 - 5 } Measurement & $\mathrm{N}$ & $\mathrm{F}$ & & $\mathrm{F}$ & $P$ \\
\hline XLF & 97 & 35.928 & $<0.001$ & 2.052 & $0.05<P<0.10$ \\
LBF & 94 & 40.896 & $<0.001$ & 2.417 & 0.043 \\
LCT & 116 & 29.601 & $<.001$ & 2.766 & 0.022 \\
XLG & 66 & 17.898 & $<.001$ & 1.735 & n.s. \\
XLH & 108 & 49.945 & $<.001$ & 2.099 & $0.05<P<0.10$ \\
XLR & 104 & 44.488 & $<0.001$ & 2.510 & $0.035<P<0.10$ \\
XLU & 93 & 40.432 & 2.291 & $0.05<P<$ \\
\hline
\end{tabular}

${ }^{1} \mathrm{XLF}$, maximum femur length; LBF, bicondylar femur length; LCT, complete tibia length; XLG, maximum fibula length; XLH maximum humerus length; XLR, maximum radius length; XLU, maximum ulna length.

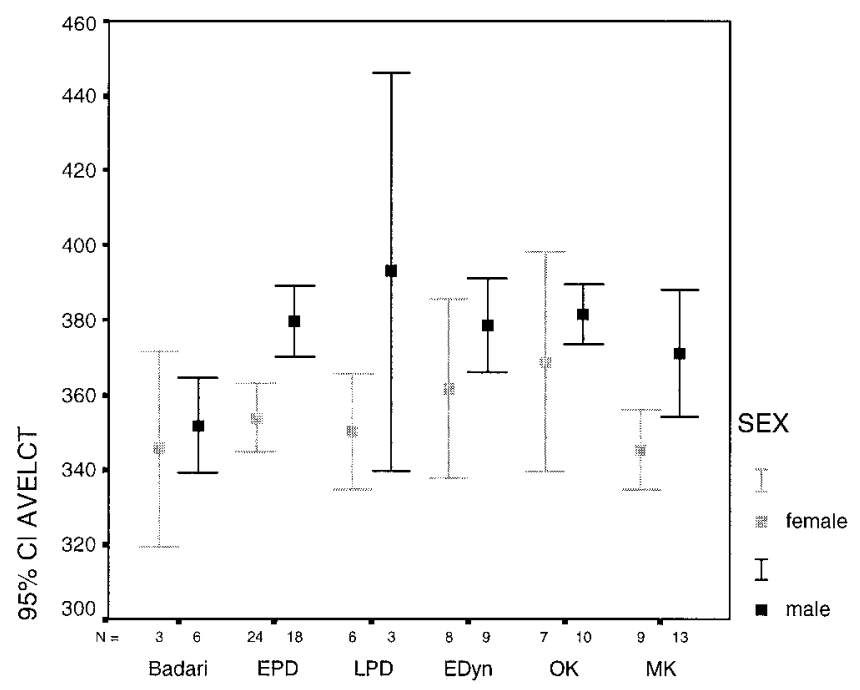

Fig. 5. Complete tibial length $(\mathrm{mm})$ by time period. Mean values, sample sizes, and $95 \%$ confidence intervals are shown.

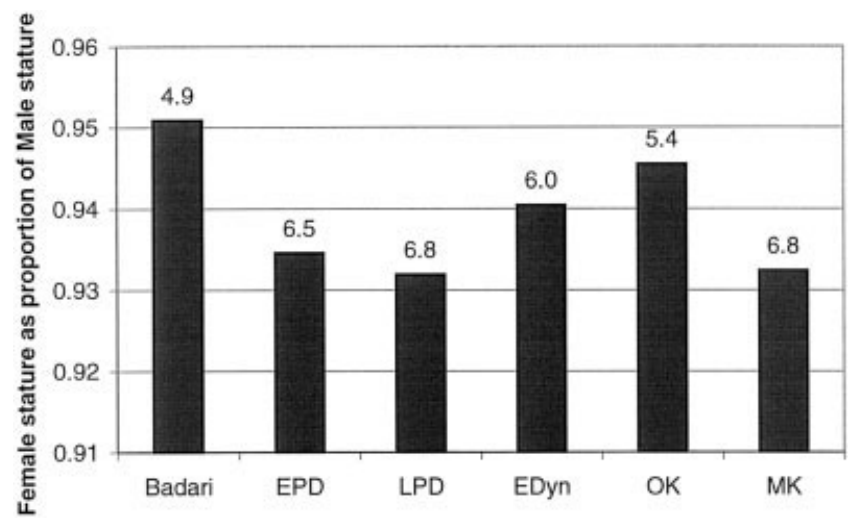

Fig. 6. Sexual dimorphism in computed adult stature by time period. The number above the bar is the \% dimorphism (D) given by $\% \mathrm{D}=100(\overline{\mathrm{M}}-\overline{\mathrm{F}}) / \overline{\mathrm{M}}$, where $\overline{\mathrm{M}}$ is the male mean, and $\overline{\mathrm{F}}$ is the female mean.

populations must be due either to functional and adaptive plasticity, or to microevolution in response to changing selective pressures.

\section{Stature and economic system}

The rapid development of intensive agriculture is predicted to have caused a decline in health status, and thus a brief reduction in stature of the early agricultural population relative to the preceding hunting, gathering, and pastoral group. This study compared a series of groups in the periods immediately following the development of agriculture, through the period of agricultural intensification and increasing social complexity. These subsistence and social changes are predicted to result not only in an increase in stature, through the increased certainty of food production, but also in an increase in variance in all measures of long bone lengths and stature as a result of an increase in differential access to and control of these resources. The model employed in this study, therefore, predicts that the earliest group, the Badarian, should have relatively short statures, and that there would be both an increase in stature and an increase in stature variance through the Predynastic periods. During the Dynastic periods, no large-scale change in economic system occurred in Egypt, although there was a change in access to resources by the working (producing) sector of the population as a series of social ranks related to trade developed. Stature is thus predicted to continue to increase overall, albeit with greater variance associated with the increase in population size and social ranking.

A significant change in stature did occur over the time periods considered. Mean calculated stature increased through the Predynastic periods, to reach a maximum in the Early Dynastic period, and then declined to the MK. Stature increased over the period of change in subsistence strategy, from pastoralism with gathering and cultivation during the Badarian period to agriculture in the Early Dynastic period, while stature declined over the phase of agricultural intensification and formation of social hierarchies (see Fig. 3). The same bow-shape pattern is also seen in all long bone lengths (e.g., Fig. 5). This pattern suggests that the Badarian sample may have suffered from some degree of growth inhibition. The increase in stature over the Predynastic periods supports the model that as agriculture became more reliable, growth stunting was reduced. The later reduction in stature is harder to explain from this model, and is more likely to be related to changes in social ranking and how well the samples represent and cross-cut the social hierarchy of the period. 
TABLE 6. ANOVA results for body segment ratios by time period, employing hierarchical model, correcting initially for sex ${ }^{1}$

\begin{tabular}{|c|c|c|c|c|c|c|c|}
\hline \multirow[b]{2}{*}{ Ratio/index } & \multirow[b]{2}{*}{ Mean value } & \multirow[b]{2}{*}{$\mathrm{s}$} & \multirow[b]{2}{*}{$\mathrm{N}$} & \multicolumn{2}{|c|}{ Sex } & \multicolumn{2}{|c|}{ Time period } \\
\hline & & & & $\mathrm{F}$ & $P$ & $\mathrm{~F}$ & $P$ \\
\hline Brachial index & 78.3 & 2.4 & 83 & 2.274 & n.s. & 1.806 & n.s. \\
\hline Crural index & 83.8 & 2.4 & 86 & 0.189 & n.s. & 1.274 & n.s. \\
\hline Intermembral I & 68.3 & 1.8 & 59 & 4.315 & 0.043 & 0.830 & n.s. \\
\hline XLH/XLU & 118 & 4.4 & 72 & 0.402 & n.s. & 2.829 & 0.023 \\
\hline XLF/XLG & 123 & 3.7 & 48 & 0.235 & n.s. & 1.976 & n.s. \\
\hline XLU/LCT & 71.0 & 2.5 & 72 & 0.003 & n.s. & 0.926 & n.s. \\
\hline XLR/LCT & 65.7 & 2.1 & $8 \overline{1}$ & 2.275 & n.s. & 0.389 & n.s. \\
\hline $\mathrm{XLH} / \mathrm{XLF}$ & 70.7 & 2.3 & 75 & 1.704 & n.s. & 2.314 & $0.05<P<0.10$ \\
\hline XLU/XLG & 73.8 & 2.4 & 49 & 0.001 & n.s. & 0.732 & n.s. \\
\hline XLR/XLG & 67.8 & 2.2 & 53 & 1.965 & n.s. & 0.421 & n.s. \\
\hline
\end{tabular}

${ }^{1}$ XLH maximum humerus length; XLU, maximum ulna length; XLR, maximum radius length; XLF, maximum femur length; XLG, maximum fibula length; LCT complete tibia length. All ratios are expressed as percentages.

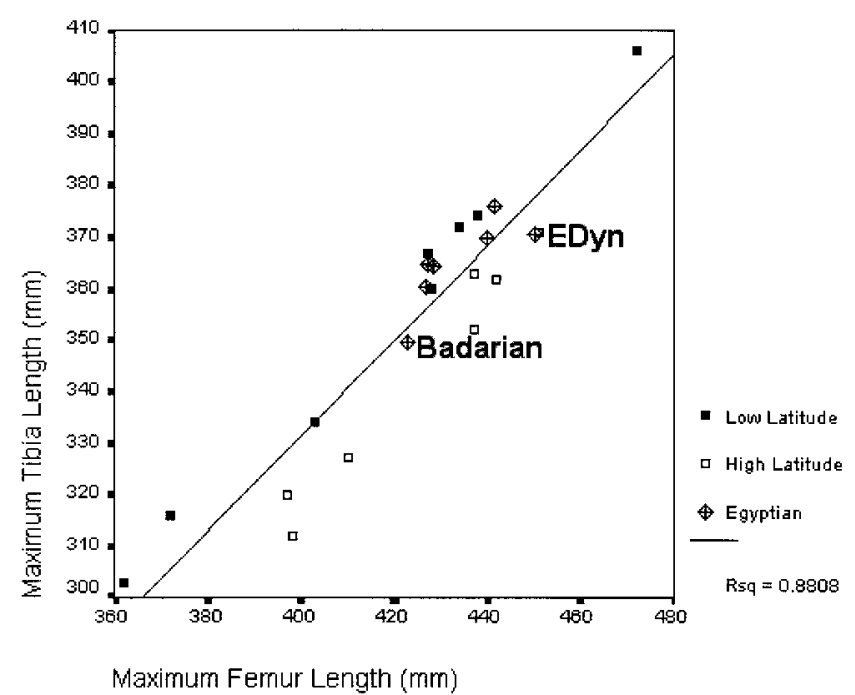

Fig. 7. Tibia length relative to femur length in ancient Egyptians, modern higher latitude populations, and tropical populations (comparative data from Ruff, 1994). Line represents approximate climatic boundary within modern samples.

\section{Stature, sexual dimorphism, and social complexity}

The increasing reliability of food production associated with agricultural intensification led to the formation of social complexity and a hierarchization of Egyptian society. This increase in social complexity was predicted to increase the variance in long bone lengths and stature, and to increase the degree of postcranial sexual dimorphism found within samples. A reduction in stature and long bone lengths was found through the Dynastic periods, although the decrease occurred most in the MK sample. If all samples studied were of similar social ranking and had similar access to resources, this would be unexpected. It is, however, possible that the earlier groups (i.e., the EDyn and OK samples) may represent higher ranked individuals than the (smaller) MK sample. The material from these groups was shown to be from cemeteries that are in proximity to royal cemeteries, such as the pyramids at Gizeh and Meidum, and hence may represent a favored group. The MK sample may also be affected by the presence of male Nubian mercenaries at Gebelein, and is supported by the greater coefficients of variation in computed adult stature of the MK male sample than the MK female sample (Fig. 4). No significant differences in computed adult stature were found between different cemeteries for the same time period (i.e., Abydos and Gebelein in the EPD, Abydos cemetery $\chi$, Abydos Tombs of the Courtiers, and el-Amrah in the EDyn, or Meidum and Gizeh in the OK).

Significant levels of sexual dimorphism were found in all long bone lengths. Overall, the Egyptian males included in this study are $6.2 \%$ larger than the females. This is slightly larger than the 5.9\% difference obtained from European Neolithic samples by Frayer (1980), but smaller than the $7.3 \%$ found in modern populations (Frayer, 1980). Egyptian males are, on average, $10.4 \mathrm{~cm}$ taller than females; the smallest difference being $8 \mathrm{~cm}$ in the Badarian sample and the greatest $11.5 \mathrm{~cm}$ in the LPD. This difference is less than the $12-13-\mathrm{cm}$ difference found in modern populations (Bogin, 1999), meaning that in modern populations, females usually have statures that are approximately $93 \%$ of those of the males (Eveleth and Tanner, 1990). Through all the periods included in this study, the women are taller relative to the males than in modern populations. As this study covers the formation of a highly socially segregated society, during which males are expected to get preferential access to food and healthcare, this result is somewhat unexpected. It may reflect the fact that women in ancient Egypt had higher status than those in most other ancient state-level societies (Watterson, 1991).

Considerable variation exists among time periods in the magnitude of sexual dimorphism found in completed statures, as indicated by Figure 6 . The female Badarian population is the tallest relative to its male counterpart (at $95 \%$ of the male stature), and hence the Badarian sample exhibits the least sexual dimorphism of the Egyptian groups studied. Modern values of stature dimorphism are $94 \%$ for white Americans and 93\% for Black Americans (Trotter and Gleser, 1952). The low dimorphism of the Badarian was predicted, as archeological evidence suggests it to be the most egalitarian of the 
groups studied (Midant-Reynes, 2000b), and therefore reasonably likely to have equal access to food and other resources. The LPD group has the highest degree of sexual dimorphism (with females at $93 \%$ of male stature). This is the period over which most social ranking and hierarchy developed, and therefore was probably associated with differential access to food and other resources. As a result, the change in sexual dimorphism during this period may be expected. Low levels of stature dimorphism were found in the EDyn and OK populations (females being between $94-95 \%$ of male statures). This pattern implies that after the development of initial social complexity, the provisioning situation became more complicated; it is possible that differential access to food may have been determined by membership in a particular social group rather than by sex, thereby reducing sexual dimorphism in stature, again reflecting the high status of women in Dynastic Egypt (Watterson, 1991). The low level of stature dimorphism may be an artifact of sampling, as the skeletal material studied includes individuals buried near royal contexts.

The change in sexual dimorphism during state formation should be considered in terms of differences in increased stature exhibited by the early Dynastic groups. As stature increased to some extent in both sexes, it follows that both sexes either prolonged the childhood and juvenile growth periods, or experienced fewer episodes of nutritional or infective stresses during childhood. For both computed stature and the raw measurements of long bone lengths, the magnitude of size change through time was greater in males than in females (the increase in computed stature between the Badarian period and the Early Dynastic period is $4.1 \%$ for males, as compared with only $2.9 \%$ for the females).

The males are thus more responsive to socioeconomic changes. Previous research among modern Mexican children also found greater biological responses to socioeconomic changes in boys than girls (Malina et al., 1985). This finding suggests that there may be several possible causes of the greater increase in growth in males:

1. Females were initially better buffered than males against the growth-inhibiting effects of disease and malnutrition in childhood. This would mean that they were already closer to reaching their genetically predisposed height during the Badarian period, and so could only increase slightly in stature with better food and health provision.

2. With the development of complex social ranking, males may have had preferential access to resources such as food and medical attention, thereby consuming more than the equivalent females.

It is likely that both possibilities played some role in modifying the growth of individuals. Figure 4 indicates that during the Early Dynastic period, greater variation is seen in female stature than in males. The variance found in measurements was predicted to be higher in the more socially ranked groups than in the more egalitarian populations. Greater variance was also predicted after population growth, such as after the LPD population expansion (Butzer, 1976). This greater female variation is surprising, as it has been shown that variability is size-dependent, and thus greater variation is predicted in males than females (Holliday and Ruff, 2001). The results described here suggest that social ranking was playing a greater role for females, with certain females differentially continuing to obtain sufficient resources, while others received less. Although in general the males were preferentially accessing food and medical resources, certain females were preferentially treated in comparison with others. No evidence of greater variance due to population increase can be found within these data. This observation may relate to the selection of Egyptian samples studied.

\section{Body shape}

Stature is comprised of contributions from several body portions, i.e., from the lower limb and from the trunk and cranium. The analyses performed on each individual bone were undertaken to see whether the small stature change found could be assigned to differences in growth of either the lower limb or the trunk (employing upper limb measurements as an indirect proxy for trunk size). Both upper and lower limb measurements (individual long bone lengths) exhibited significant change through time, although neither upper limb length (humerus + radius) nor lower limb length (femur + tibia) themselves exhibited significant change through time. All long bone lengths that changed display the same trend of increasing in length up until the start of the Dynastic period, and then decrease to the MK. None of the body ratios separating upper and lower portions exhibit statistically significant change through time. This pattern supports suggestions that the relative constancy of stature (i.e., the relatively low level of change through time) cannot easily be compartmentalized. This result is in agreement with previous research that found no significant change in body proportions between the Predynastic period and the Middle Kingdom (Masali, 1972; Robins, 1983).

The ancient Egyptians have been described as having a "Negroid" body plan (Robins, 1983). Variations in the proximal to distal segments of each limb were therefore examined. Of the ratios considered, only maximum humerus length to maximum ulna length (XLH/XLU) showed statistically significant change through time. This change was a relative decrease in the length of the humerus as compared with the ulna, suggesting the development of an increasingly African body plan with time. This may also be the result of Nubian mercenaries being included in the sample from Gebelein. 
The nature of the body plan was also investigated by comparing the intermembral, brachial, and crural indices for these samples with values obtained from the literature. No significant differences were found in either index through time for either sex. The raw values in Table 6 suggest that Egyptians had the "super-Negroid" body plan described by Robins (1983). The values for the brachial and crural indices show that the distal segments of each limb are longer relative to the proximal segments than in many "African" populations (data from Aiello and Dean, 1990). This pattern is supported by Figure 7 (a plot of population mean femoral and tibial lengths; data from Ruff, 1994), which indicates that the Egyptians generally have tropical body plans. Of the Egyptian samples, only the Badarian and Early Dynastic period populations have shorter tibiae than predicted from femoral length. Despite these differences, all samples lie relatively clustered together as compared to the other populations.

\section{Social context of samples}

Although the sites were not chosen for their historical context (as samples were chosen for reliability of dating and provenance, completeness, and accessibility), there are certain important factors to consider.

This study concentrated on the period of state formation and intensification of agriculture, and the Abydos region was at the heart of the state-formation process (Wilkinson, 1999). The town is located in the region of richest resources, and so may have had a greater capacity to produce and control surplus foods and other resources. It also lies at the crossroads of trade with the western oases and the upper Nile Valley (Bard, 1994). This position suggests that, together with its links with the early pharaohs, the cemeteries may not be truly representative of the periods from which they originate. The individuals buried may be higher socially ranked than people from other areas, and thus may have better access to food. Like Abydos, Gizeh was also in an area with greater control of trade, through its location as the linking point between the Nile Valley and the Delta. The OK material from Gizeh, therefore, may be different from that originating from Meidum, as Gizeh may have had greater social differentiation, although no statistically significant differences were found between these samples (which may reflect their royal nature).

The earliest evidence of Nubians living in Egypt comes during the OK. Throughout the MK, the pharaonic frontier lay on the Second Cataract (in present-day Sudan); during this period, movements northwards from Nubia are especially likely. Together with the known presence of Nubian mercenaries in Gebelein (Fischer, 1961), the MK sample may represent a Nubian rather than Egyptian population.

\section{CONCLUSIONS}

This study found an increase in stature within Egyptians from the Predynastic until the start of the Dynastic period, followed by a later decline in height. The increase in stature with intensification of agriculture was predicted as a result of greater reliability of food production and the formation of social ranking. The later decrease in stature coincides with even greater social complexity, and is expected as it implies that the formation of social classes is allied to differential access to nutrition and healthcare, with the higher ranked individuals being preferentially treated and fed. This change in stature was much greater in males than in females. Long bone lengths also increased from the Badarian to the Early Dynastic periods more for males than for females, and again decreased to a greater extent through the OK and MK periods among males than females. This greater response to changes in socioeconomic status by males was previously described in modern children (Malina et al., 1985; Stinson, 1985). The present study thus supports the greater response to environmental stresses, including positive stresses, in males than in females.

The present study suggests that changes in stature and body size occurred in Egypt with the development of social ranking, through a reflection of differential access to food and other resources. These results must remain provisional due to the relatively small sample sizes and the lack of skeletal material that cross-cuts all social and economic groups within each time period. Further research on recently excavated skeletal material is therefore needed to further address the issues raised.

\section{ACKNOWLEDGMENTS}

I thank the following curators for allowing access to skeletons: M. Bellatti, R. Boano, R. Foley, L. Humphrey, R. Kruszynski, M. Lahr, E. RabinoMassa, and M. Teschler-Nicola. Thanks also go to R. Foley and M. Lahr and three anonymous reviewers for comments on earlier versions of this paper.

\section{LITERATURE CITED}

Aiello L, Dean C. 1990 An introduction to human evolutionary anatomy. London: Academic Press.

Aldred C. 1998. The Egyptians. London: Thames and Hudson, Ltd.

Allison MJ. 1984. Paleopathology in Peruvian and Chilean populations. In: Cohen MN, Armelagos GJ, editors. Paleopathology at the origins of agriculture. New York: Academic Press. p 515-529.

Angel JL. 1972. Biological relations of Egyptian and Eastern Mediterranean populations during Pre-dynastic and Dynastic times. J Hum Evol 1:307-313.

Angel JL. 1984. Health as a crucial factor in the changes from hunting to developed farming in the Mediterranean. In: Cohen MN, Armelagos GJ, editors. Paleopathology at the origins of agriculture. New York: Academic Press. p 51-74.

Bard KA. 1994. From farmers to pharoahs. Sheffield: Sheffield Academic Press.

Bogin B. 1999. Patterns of human growth. Cambridge: Cambridge University Press. 
Bräuer G. 1988. Osteometrie. In: Knussmann R, editor. Anthropologie: Handbuch der vergleichenden Biologie des Menschen. Stuttgart: Gustav Fischer.p 160-232.

Brewer DJ, Friedman RF. 1989. Fish and fishing in ancient Egypt. Warminster: Aris \& Phillips.

Brewer DJ, Teeter E. 1999. Egypt and the Egyptians. Cambridge: Cambridge University Press.

Brewer DJ, Redford DB, Redford S. 1994. Domestic plants and animals: the Egyptian origins. Warminster: Aris \& Phillips.

Brunton G, Caton-Thompson G. 1928. The Badarian civilisation and Predynastic remains near Badari. London: Bernard Quaritch.

Butzer KW. 1976. Early hydraulic civilization in Egypt: a study in cultural ecology. Chicago: University of Chicago Press.

Castillos JJ. 1983. A study of the spatial distribution of large and richly endowed tombs in Egyptian Predynastic and Early Dynastic cemeteries. Toronto: Private Publication.

Cohen MN. 1989a. Health and the rise of civilization. New Haven: Yale University Press.

Cohen MN. 1989b. Paleopathology and the interpretation of economic change in prehistory. In: Lamberg-Karlovsky CC, editor. Archeological thought in America. Cambridge: Cambridge University Press. p 117-132.

Cook DC. 1984. Subsistence and health in the Lower Illinois Valley: osteological evidence. In: Cohen MN, Armelagos GJ, editors. Paleopathology at the origins of agriculture. New York: Academic Press. p 237-270.

Darby WJ, Ghalioungui P, Grivetti L. 1977. Food: the gift of Osiris. London: Academic Press.

Duhig C. 2000. "They are eating people here!" Skeletal indicators of stress in the Egyptian First Intermediate Period. Unpublished Ph.D. dissertation, University of Cambridge.

Eveleth PB, Tanner JM. 1990. Worldwide variation in human growth. Cambridge: Cambridge University Press.

Fischer HG. 1961. The Nubian mercenaries of Gebelein during the First Intermediate Period. Kush 9:44-80.

Frayer DW. 1980. Sexual dimorphism and cultural evolution in the Late Pleistocene and Holocene of Europe. J Hum Evol 9:399-415

Golden MHN. 1996. The effect of early nutrition on later growth. In: Henry CJK, Ulijaszek SJ, editors. Long-term consequences of early environment: growth, development and the lifespan developmental perspective. Cambridge: Cambridge University Press. p 91-108.

Goodman AH, Lallo J, Armelagos GJ, Rose JC. 1984. Health changes at the Dickson Mounds, Illinois (AD 950-1300). In: Cohen MN, Armelagos GJ, editors. Paleopathology at the origins of agriculture. New York: Academic Press. p 271-305.

Harrison GA. 1992. Human genetics and variation. In: Harrison GA, Tanner JM, Pilbeam DR, Baker PT, editors. Human biology. Oxford: Oxford University Press. p 145-336.

Haviland WA. 1967. Stature at Tikal, Guatemala: implications for ancient Maya demography and social organization. Am Antiq 32:316-325.

Hendrickx S, Vermeersch P. 2000. Prehistory: from the Palaeolithic to the Badarian culture. In: Shaw I, editor. The Oxford history of ancient Egypt. Oxford: Oxford University Press. p $17-43$.

Hoffman MA. 1979. Egypt before the Pharaohs. New York: Alfred A. Knopf.

Holliday TW, Ruff CB. 2001. Relative variation in human proximal and distal limb segment lengths. Am J Phys Anthropol 116:26-33.

King SE, Ulijaszek SJ. 1999. Invisible insults during growth and development: contemporary theories and past populations. In: Hoppa RD, FitzGerald CM, editors. Human growth in the past: studies from bones and teeth. Cambridge: Cambridge University Press. p 161-182.

Larsen CS. 1984. Health and disease in prehistoric Georgia: the transition to agriculture. In: Cohen MN, Armelagos GJ, editors. Paleopathology at the origins of agriculture. New York: Academic Press. p 367-392.
Larsen CS. 1995. Biological changes in human populations with agriculture. Annu Rev Anthropol 24:185-213.

Larsen CS. 1997. Bioarchaeology: interpreting behaviour from the human skeleton. Cambridge: Cambridge University Press.

Leek FF. 1986. Cheops' courtiers: their skeletal remains. In: David AR, editor. Science in Egyptology. Manchester: Manchester University Press. p 183-199.

Malek J. 2000. The Old Kingdom. In: Shaw I, editor. The Oxford history of ancient Egypt. Oxford: Oxford University Press.

Malina RM, Bouchard C. 1991. Growth, maturation and physical activity. Champaign, IL: Human Kinetics Books. p 89-117.

Malina RM, Little BB, Buschang PH, DeMoss J, Selby HA. 1985. Socioeconomic variation in the growth status of children in a subsistence agricultural community. Am J Phys Anthropol 68: $385-391$.

Martin DL, Armelagos GJ, Goodman AH, Van Gerven DP. 1984. The effects of socioeconomic change in prehistoric Africa: $\mathrm{Su}-$ danese Nubia as a case study. In: Cohen MN, Armelagos GJ, editors. Paleopathology at the origins of agriculture. Orlando: Academic Press. p 193-214.

Martin R, Saller K. 1957. Lehrbuch der Anthropologie. Stuttgart: Fischer.

Martorell R, Habicht J-P. 1986. Growth in early childhood in developing countries. In: Falkner F, Tanner JM, editors. Human growth: a comprehensive treatise. New York: Plenum Press. p 241-262.

Masali M. 1972. Body size and proportions as revealed by bone measurements and their meaning in environmental adaptation. J. Hum Evol 1:187-197.

Meiklejohn C, Schentag C, Venema A, Key P. 1984. Socioeconomic change and patterns of pathology and variation in the Mesolithic and Neolithic of Western Europe: some suggestions. In: Cohen MN, Armelagos GJ, editors. Paleopathology at the origins of agriculture. New York: Academic Press. p 75-100.

Midant-Reynes B. 2000a. The Naqada Period. In: Shaw I, editor. The Oxford history of ancient Egypt. Oxford: Oxford University Press.

Midant-Reynes B. 2000b. The prehistory of Egypt. Oxford: Blackwell.

Petrie WMF. 1892. Medum. London: David Nutt. p 44-60.

Robins G. 1983. Natural and canonical proportions in ancient Egyptians. Gottinger Miszellen 61:17-25.

Robins G, Shute CCD. 1986. Predynastic Egyptian stature and physical proportions. Hum Evol 1:313-324.

Ruff CB. 1994. Morphological adaptation to climate in modern and fossil hominids. Yrbk Phys Anthropol 37:65-107.

Schoeninger MJ. 1979. Diet and status at Chalcatzingo: some empirical and technical aspects of strontium analysis. Am J Phys Anthropol 51:295-310.

Sinclair DC. 1989. Human growth after birth. Oxford: Oxford University Press.

Sokal RR, Rohlf FJ. 1995. Biometry. New York: W.H. Freeman.

Steegmann AT Jr, Haseley PA. 1988. Stature variation in the British American colonies: French and Indian War records, 1755-1763. Am J Phys Anthropol 75:413-421.

Stinson S. 1985. Sex differences in environmental sensitivity during growth and development. Yrbk Phys Anthropol 28:123147.

Trigger BG. 1983. The rise of Egyptian civilization. In: Trigger BG, Kemp BJ, O'Connor D, Lloyd AB, editors. Ancient Egypt: a social history. Cambridge: Cambridge University Press. p 1-70.

Trotter M, Gleser GC. 1952. Estimation of stature from long bones of American whites and Negroes. Am J Phys Anthropol 10:463-514.

Ulijaszek SJ, Strickland SS. 1993. Nutritional anthropology: prospects and perspectives. London: Smith-Gordon.

Watterson B. 1991. Women in ancient Egypt. Stroud: Alan Sutton Publishing.

White CD, Healy PF, Schwarcz HP. 1993. Intensive agriculture, social status, and Maya diet at Pacbitun, Belize. J Anthropol Res 49:347-375.

Wilkinson TAH. 1999. Early Dynastic Egypt. London: Routledge. 